\title{
IMUNITAS HUKUM BAGI NOTARIS YANG MEMBUKA RAHASIA DALAM PERSIDANGAN
}

\author{
Annisa \\ Program Studi Magister Kenotariatan PPS Unisma \\ Jalan Mayjen Haryono Nomor 193 Malang \\ Email: icha29_mulyani08@gmail.com
}

\begin{abstract}
Abstrak
Penelitian ini memiliki tujuan untuk memaparkan mengenai konsep ideal imunitas hukum bagi notaris ditinjau dari segi peraturan perundangundangan di Indonesia dan perlindungan hukum terhadap notaris yang membuka kerahasiaan isi akta di pengadilan. Konsep ideal imunitas bagi notaris yang didapat dalam penelitian ini adalah dimana notaris dapat perlindungan hukum dari kemungkinan terkena sanksi karena menjalankan kewajiban sebagai saksi dan melindungi notaris dari akta yang bermasalah, dengan konteks pembuatan akta yang secara administrative adalah benar namun dalam proses pengkonstantiran kedalam bentuk akta, terjadi manipulasi data oleh klien tanpa sepengetahuan notaris.

Kata Kunci: imunitas hukum, perlindungan hukum, kerahasiaan

Abstract

This research aim to explain about ideal concept of legal immunity to a notary reviewed from legislation aspects in Indonesia and legal protection toward notary which reveal the secrecy of deed contents in the court. Ideal concept of immunity to a notary that has been found in this research is where the notary receive legal protection from the probability of given sanctions because of perform the duty as a witness and protect the notary from problematic deed, with the context that deed making administratively is right yet in process of to the deed form, there were data manipulation done by the client without notary known.
\end{abstract}

Keywords: Legal Immunity, Legal Protection, Secrecy 


\section{PENDAHULUAN}

Dewasa ini kebutuhan masyarakat akan jasa Notaris sebagai pejabat pembuat akta semakin meningkat di dalam kehidupan sehari-hari, hal ini di karenakan semakin tingginya kebutuhan orang atau badan hukum dalam melakukan perjanjian-perjanjian yang dituangkan dalam akta. Kewenangan yang dimiliki Notaris ini tidak lepas dari fungsi Notaris itu sendiri sebagai pejabat public yang memilik wewenang untuk menerbitkan suatu akta autentik mengenai semua perbuatan, perjanjian dan penetapan yang diperintahkan oleh peraturan umum atau diminta oleh para pihak yang membuat akta. ${ }^{1}$

Akta autentik menurut Pasal 1868 KUHPerdata diartikan sebagai suatu akta yang dibuat dalam bentuk yang telah ditentukan oleh UndangUndang oleh pejabat umum atau dihadapan pejabat umum yang berwenang membuat akta tersebut.Akta autentik yang dikeluarkan oleh pejabat umum, dalam hal ini notaris memiliki kepastian hukum yang jelas.Untuk itu kode etik bagi profesi Notaris-pun diperlukan untuk menjaga konsistensi atau meningkatkan kualitas pelayanan hukum.

Jabatan Notaris adalah jabatan yang bersinggungan dengan kata "kepercayaan".Undang-Undang telah memberikan ultimatum dimana para Notaris selain berwenang untuk membuat suatu akta autentik namun juga harus menjaga kerahasian para kliennya.Namun, dalam prakteknya, seringkali Notaris terlibat dengan perkara hukum baik sebagai saksi maupun sebagai tersangka. Keterlibatan notaris dalam perkara hukum tidak hanya terjadi karena adanya kesalahan dalam pembuatan akta, namun juga bisa disebabkan faktor lain seperti pemalsuan dokumen, dimana akta notaris tersebut dipalsukan oleh pihak lain tanpa sepengetahuan Notaris dan pihak yang berkaitan dengan akta notarial yang asli. Sehingga menyebabkan kerugian dari pihak yang asli maupun Notaris yang terkait.

Tahapan dalam proses peradilan pidana, terdapat proses pembuktian yang mana jenis bukti yang dapat dibawa kedalam persidangan yang jika dilihat dalam Pasal 184 KUHP, yaitu keterangan saksi, keterangan ahli, surat, petunjuk, dan juga keterangan terdakwa.

Jika seorang notaris terjebak dalam situasi perkara pidana, dimana akta yang dibuatnya dijadikan sebagai salah satu bukti untuk memperoleh kebenaran materil, secara pasti notaris dihadapkan pada situasi dimana situasi tersebut sangat bisa mengancam profesinya. Hal ini karna jelas, bahwa membuka isi akta dimuka pengadilan sama dengan membuka

\footnotetext{
${ }^{1}$ Sudikno Mertokusumo, “ArtiPenemuan Hukum Bagi Notaris” Majalah Renvoi,
} Nomor 12, tanggal 3 Mei 2004,hal. 49 
kerahasiaan klien yang bertentangan dengan Pasal 16 ayat 1 huruf $f$ UUNJP.

Masalah lain akan muncul jika notaris menolak menjadi saksi dan atau menolak memberikan keterangan sebagai saksi. Hal ini karena berdasarkan Pasal 522 KUHP yang menyatakan : "barangsiapa yang dipanggil menurut undang-unang untuk menjadi saksi ahli atau juru bahasa, tidak datang secaram melawan hukum. Diancam dengan pidana denda paling bsnysk sembilan ratus rupiah". Dilematis seorang notaris kembali diuji, ketika memilih menjalankan ketentuan yang terdapat dalam Pasal 16 ayat 1 huruf $\mathrm{f}$ UUN-P, seorang notaris dapat dikenai sanksi berupa teguran hinga pemberhentian tidak hormat sesuai dengan ketentuan yang tertulis dalam Pasal 66 undang-undang yang sama, atau dapat pula dikenakan Pasal 322 KUHP yang berkenaan dengan sanksi administrasi

Ini tentu saja dirasa tidak adil bagi Notaris, dimana para Notaris dihadapkan pada keharusan untuk menjadi saksi agar terlaksananya system peradilan yang baik, namun disisi lain para praktisi tersebut harus tunduk pada Undang-Undang yang mengancam perbuatan membuka rahasia dengan sanksi.

Seperti halnya hak imunitas yang dimiliki Advokat dan beberapa profesi lainnya, yang menyatakan bahwa dalam menjalankan profesi, selama itu sesuai dengan peraturan, maka profesi tersebut tidak dituntut.Berkenaan dengan hal tersebut maka tujuan dari penelitian ini adalah memaparkan mengenai konsep ideal imunitas hukum bagi notaris ditinjau dari segi peraturan perundang-undangan di Indonesia dan perlindungan hukum terhadap notaris yang membuka kerahasiaan isi akta di pengadilan.

\section{METODE PENELITIAN}

Jenis penelitian yang digunakan adalah jenis penelitian YuridisNormatif.Untuk mengkaji pokok permasalahan, penelitian ini mempergunakan metode penelitian hukum normative,untuk itu yang menjadi focus dan sentral penelitian ini adalah berbagai aturan hukum dan literature atau bahan yang berkaitan dengan hukum.Pendekatan yang digunakan dalam hal penelitian bahan pustaka pada penelitian ini adalah pendekatan perundang-undangan (statute approach), pendekatan ini dilakukan untuk menelaah dan memahami semua undang-undang dan regulasi yang terkait dengan isu hukum yang sedang penulis teliti.Penelitian ini juga mengunakan pendekatan konseptual (konseptual approach).Pendekatan yang bersifat yuridis-normatif tersebut akan dilakukan dengan mempergunakan bahan hukum primer, bahan hukum 
sekunder dan bahan hukum tersier. ${ }^{2}$ Teknik pengumpulan bahan hukum yang digunakanadalah studi pustakan dengan analisis menggunakan metode penelitian deskriptif-kualitatif.

\section{PEMBAHASAN}

\section{Konsep Ideal Imunitas Hukum Bagi Notaris Ditinjau Dari Segi Peraturan Perundang-Undangan Di Indonesia}

1. Notaris dengan Hak Imunias di Indonesia

Sebelum membahas mengenai bagaimana konsep yang ideal mengenai hak imunitas bagi notaris, alangkah lebih baiknya untuk mengetahui bagaimana hubungan hukum dari profesi notaris itu sendiri sebagai pejabat umum dengan hak imunitas profesi yang sudah berlaku di Indonesia.Hal ini dibutuhkan guna untuk menemukan konsep imunitas hukum yang tepat bagi notaris.Sehingga diharapkan notaris mendapatkan perlindungan hukum yang pasti dalam menjalankan kewajibannya terhadap beban tanggung jawab profesi yang diembannya.

Salah satu kewajiban seorang notaris yang krusial sebagai pejabat umum, yang notabenenya sebagai pekerja public adalah menjaga kerahasiaan suatu akta yang dibuatnya berdasarkan keinginan kliennya. Hal ini sesuai dengan maksud dari Pasal 16 ayat 1 huruf $\mathrm{f}$ UUJN dimana notaris dituntut untuk menjaga segala sesuatu yang berkenaan dengan akta yang dibuatnya sesuai dengan sumpah janji jabatan, kecuali undang-undang menentukan lain.

Frasa kecuali undang-undang menentukan lain menjadikan peraturan mengenai kerahasiaan akta menjadi dilemma tersendiri oleh notaris. Hal ini karena dalam satu pasal dinyatakan jelas dan tegas bahwa seorang notaris harus menjaga kerahasiaan akta yang dibuatnya, namun di pasal yang sama pula terdapat frasa yang mengindikasikan ada kebimbangan dalam menentukan posisi dari kekuatan isi pasal tersebut.

Melihat dari sudut pandang hirarki hukum, dimana hukum yang tingkatannya lebih tinggi didahulukan keberlakuannya daripada hukum yang lebih rendah (lex superuior derogate legi inferior) dan/atau aturan hukum yang lebih khusus mengesampingkan aturan hukum yang lebih umum (lex specialis derogate legi generalis), maka kalimat "kecuali undang-undang menentukan lain" pada pasal tersebut akan menjadi frasa yang akan melunturkan kewajiban notaris untuk menjaga sebuah kerahasiaan suatu akta. Sedangkan diketahui

${ }^{2}$ Ibid, hal. 29. 
bersama bahwa kewajiban dalam kepentingan menjaga rahasia sangat urgen untuk memberikan rasa aman, baik kepada para pihak yang menghadap untuk dibuatkan akta autentik ataupun notaris itu sendiri.

Perlindungan hukum dalam suatu imunitas hukum akan memberikan kepastian hukum terhadap isi akta. Dengan begitu keabsahan isi akta bisa dipertanggung jawabkan dan memiliki kekuatan hukum tetap.

Dalam hal membicarakan imunitas hukum, tentu tidak lepas dari profesi yang mendapatkan hak imunitas, dimana hak imunitas tersebut aktif untuk melindungi individu terebut dan diatur dalam undangundang dalam bentuk lex specialis sebagai landasan hukum yang pasti. Dalam hukum dikenal 2 hak imunitas, yaitu : (1) hak imunitas mutlak, yaitu hak imunitas yang berlaku secara mutlak atau tetap sehingga tidak ada satu orangpun yang dapat membatalkannya; (2) hak imuntas relative, dimana hak imunitas ini masih bisa dikesampingkan.

Pada dasarnya semua jabatan dan profesi berhak atas hak imunitas guna melindungi personal mereka dalam melaksanakan profesinya yang dijalankan dengan iktikad baik.Berdasarkan pernyataan tersebut, dapat ditarik kesimpulan bahwa imunitas lahir untuk melindungi hak-hak manusia sebagai individu dari beban tanggung jawab pekerjaan ataupun jabatan yang diembannya.

Sebuah imunitas hukum yang diberikan kepada sebuah jabatan atau profesi akan sangat tergantung pada kedudukan pejabat ataupun profesi tersebut, seperti halnya hak imunitas yang diberikan kepada badan hukum dan karyawan bank untuk menjaga kerahasiaan data pribadi dan rekening nasabahnya yang di tuangkan dalam bentuk Pasal 40 ayat (1) UU Perbangkan dan Pasal 2 ayat (1) PBI 2/19/PBI/2000. Kemudian hak imunitas lain juga terdapat pada Lembaga Pers yang memiliki hak ingkar atau hak tolak yang tertuang jelas dalam Pasal 4 ayat 4 UUPers dan pada Pasal 8 undang-undang yang sama disebutkan bahwa dalam melaksanakan tugasnya seorang jurnalis mendapatkan perlindungan hukum, hal ini dalam rangka melindungi personal jurnalis selama ia menjalankan tugasnnya dalam hal pencarian berita yang berkaitan dengan kerahasiaan data pribadi narasumbernya. Serta profesi Advokat yang juga memiliki hak imunitas di depan pengadilan, dimana para advokat dinyatakan tidak dapat dihukum selama menjalankan tugas profesinya dengan iktikad baik dalam hal pembelaan klien dimuka siding, pernyataan tersebut tertuang jelas dalam Pasal 16 UU Advokat. 
Berkaitan dengan kewajiban Notaris untuk merahasiakan isi akta, terdapat sebuah imunitas namun sifatnya masih dalam bentuk perundang-undangan yang umum (lex generalis) tidak seperti pada tiga profesi diatas yang jelas disebutkan dalam Undang-Undang yang mengatur profesi mereka bahwa mereka (pekerja profesi tersebut) diberikan hak imunitas selama menjalankan profesinya sesuai dengan aturan tersebut (sistem limitatif). ${ }^{3}$

Hak imunitas notaris dalam hal kerahasiaan yaitu terdapat dalam Pasal 170 ayat (1) KUHAP menyatakan:Mereka yang karena pekerjaan, harkat martabat atau jabatannya diwajibkanmenyimpan rahasia dapat minta dibebaskan dari kewajiban untuk memberiketerangan sebagai saksi, yaitu tentang hal yang dipercayakan kepada mereka.

Dari sini dapat dikatakan bahwa kerahasiaan notaris masuk kedalam kategori kerahasiaan :

1. Kerahasiaan Notaris masuk kedalam kategori kerahasiaan pekerjaan $^{4}$ yang mana kerahasiaan notaris berkaitan erat dengan kerahasiaan akta yang dibuatnya. Akta sendiri merupakan bagian dari kegiatan seorang notaris saat menjalankan jabatannya.

2. Kerahasiaan notaris termasuk kedalam kerahasiaan dengan sistem blanko, dimana undang-undang yang menjadi dasar hak imunitas notaris masih bersifat terlalu umum dan tanpa kreteria yang jelas, sehingga bukan tidak mungkin akan menimbuklan ketidakpastian hukum bagi notaris itu sendiri karna undang-undang tersebut masih bebas luas ditafsirkan oleh hakim. ${ }^{5}$

Jika melihat Hak Ingkar ${ }^{6}$ yang terdapat dalam UUJN, hal tersebut dirasa belum bisa melindungi personal individu notaris dari jeratan pidana, karena hak ingkar ini sangat terbatas. Jika benar bisa direalisasikan secara maksimal, dengan adanya hak ingkar maka

${ }^{3}$ Ko Tjay Sing, Rahasia Pekerjaan Dokter dan Advokat, (Jakarta: PT Gramedia ,1978), hal. 13

${ }^{4}$ Rahasia pekerjaan adalah rahasia yang berkaitan dengan profesionalitas (kegiatan saat menjalankan jabatannya)

${ }^{5}$ Ko Tjay Sing, Op. Cit, hal.8

${ }^{6} \mathrm{Hak}$ ingkar adalah hak untuk menolak memberi keterangan tentang sesuatu rahasia yang berkaitan dengan jabatannya atau akta yang dibuatnya dan keteranganketerangan yang diperoleh guna pembuatan akta, sesuai sumpah atau janji jabatan.

https://osf.io/ag3vh/ diakses pada tanggal 23 Juni 2019. Laurensius Arliman S., "Ingkar (Verschoningsplicht) Atau Kewajiban Ingkar (Verschoning Splicht) Notaris Didalam Undang-Undang Jabatan Notaris", Jurnal hukum Doctrinal, Vol.1, Nomor 1, 2016. 
dalam suatu proses pemeriksaan baik di tingkat penyelidikan, penyidikan, maupun pada saat proses persidangan, sikap dari notaris adalah pasif, dalam arti memberikan keterangan sebatas hal-hal yang menyangkut pelaksanaan jabatan saja. Keharusan untuk menjaga rahasia itu wajib dilakukan bukan saja menjaga kerahasian dari isi akta, tetapi juga merahasiakan segala keterangan yang diperolehnya. menjaga martabat dan kehormatan notaris dalam menjalankan profesi jabatannya serta memberikan perlindungan kepada notaris terkait dengan kewajiban merahasiakan isi akta. Jadi disini yang dilindungi adalah jabatannya bukan pejabatnya.

Dengan kata lain pejabat atau individu notaris tidak mendapatkan perlindungan hukum yang melekat kepadanya. Tidak adanya perlindungan hukum yang melekat kepada pejabat notaris akan membuat notaris tidak memiliki kekuatan hukum yang kuat dalam menolak atapun berargumen dalam mempertahankan akta yang dibuka dalam sebuah persidangan.

Notaris yang merupakan sebuah profesi yang bersinggungan dengan hukum, sewajarnya juga harus memiliki hak imunitas. Adanya perlindungan dan kepastian hukum yang diberikan imunitas hukum kepada notaris dalam hal perlindungan hukum terhadap notaris yang membuka isi akta dimuka persidangan dapat memberikan rasa aman kepada notaris dari tuntutan kewajiban notaris untuk merahasiakan akta dan juga dari jeratan pidana yang terdapat dalam KUHP seperti yang tertulis berdasarkan ketentuan Pasal 322 ayat (1) KUHP yang mana dalam ketentuan tersebut menyatakan bahwa bagi siapapun yang dengan sengaja baik karna terpaksa maupun tidak diketahui membuka rahasia yang seharusnya menjadi kewajibannya dalam rangka melaksanakan kewajiban jabatannya, dapat dikenakan sanksi pidana 9 bulan penjara atau denda paling banyak Rp. 600,-

Isi KUHP tersebut bisa saja menjerat notaris ke ranah pidana jika notaris membuka rahasia isi akta di depan pengadilan, karena hal itu bisa dianggap merugikan klien yang memiliki akta tersebut. Dilema kepentingan seperti ini akan bisa teratasi dengan adanya imunitas hukum kepada notaris dalam hal membuka rahasia isi akta di depan pengadilan. Pentingnya imunitas hukum untuk melindungi pejabat notaris dalam hal membuka kerahasiaan isi akta, akan sangat menunjang kinerja profesi notaris.

Adanya perlindungan hukum dan kepastian hukum yang melekat pada imunitas yang diberikan kepada notaris dapat memberikan rasa aman terhadap notaris. Disisi lain imunitas hukum ini sendiri akan memberikan kemudahan kepada pengadilan untuk 
membuka isi akta tanpa harus ada perlawanan dari hak ingkar yang dimiliki notaris, sehingga kegiatan pembuktian dipengadilan akan cepat dan tepat dalam pelaksanaannya.

\section{Konsep Ideal Imunitas Hukum Bagi Notaris.}

Kebutuhan akan imunitas hukum bagi profesi notaris untuk melindungi pejabat notaris, tidak terlepas dari kurangnya perlindungan dan kepastian hukum didalam hak notaris yang dimiliki. Didalam sebuah persidangan untuk pembuktian sebuah akta, tidak jarang seorang notaris akan dipaksa untuk mengeluarkan isi akta dimana pada sisi lain notaris berkewajiban untuk merahasiakan isi akta tersebut, dilema kepentingan ini bisa menyeret notaris untuk berkhianat kepada kewajibannya yang mengharuskan notaris agar menjaga kerahasiaan akta yang dikeluarkannya.

Semetara itu klien sebagai pemilik akta juga bisa menyeret notaris ke ranah pidana seperti yang terdapat pada ketentuan Pasal 322 KUHP ayat (1)yang menyatakan bahwa jika seorang pejabat (dalam hal ini adalah notaris) membuka rahasia akta maka iadapat dikenai sanksi pidana berupa kurungan penjara selama 9 bulan atay denda Rp.600,-. Dijelaskan pula dalam ayat 2 peraturan perundang-undangan yang sama, bahwa jika perbuatan membongkar rahasia tersebut ditujukan untuk orang atau kelompok tertentu maka perbuatan tersebut bisa dituntut atas pengaduan dari pihak yang merasa dirugikan. Dengan peraturan perundang-undangan tersebut maka posisi notaris akan sangat disudutkan.

Dalam hal ini, benar atau tidaknya tindakan notaris untuk membuka rahasia sebuah akta didepan pengadilan menurut pendapat penulis itu akan sangat tergantung pada tolak ukur kepentingan dalam mencari suatu keadilan.

Dilema dalam menentukan perlindungan untuk imunitas hukum bagi notaris membawa kita kepada suatu konsep yang ideal untuk melindungi notaris dari jeratan pelanggaran pidana dan pelanggaran kewajiban dalam hal melindungi isi akta.Terdapat dua sisi yang berbeda dalam menentukan imunitas hukum bagi notaris ini, dimana sisi perlindungan dan kepastian hukum harus ditegakkan tetapi tidak melupakan sisi keadilan dalam mencari suatu kebenaran dipengadilan.

Konsep ideal harus benar-benar memikirkan jalan terbaik demi menjunjung tinggi perlindungan hukum dan kepastian hukum serta tidak melupakan rasa keadilan didalamnya. Konsep yang ideal menurut penulis dimana ini akan mementingkan perlindungan dan kepastian hukum untuk notaris tetapi juga tidak mengganggu rasa 
keadilan bagi notaris, klien, dan persidangan dalam mencari sebuah kebenaran.

Imunitas hukum yang ideal bagi Notaris dalam pandangan penulis yang bisa mencakup perlindungan hukum, kepastian hukum, dan rasa keadilan hukum yang tepat adalah:

a. Notaris dilindungi oleh hak Imunitas saat membuka rahasia isi akta. Hal ini untuk melindungi Notaris dalam konteks membuka rahasia akta yang seharusnya tidak boleh dibuka di depan umum (pengadilan).

1. Imunitas ini mengakomodir perlindungan hukum bagi notaris dari kemungkinan terkena ancaman pidana berdasarkan Pasal 322 KUHP ayat (1) yang menyatakan bahwa:

Barang siapa dengan sengaja membuka rahasia yang wajib disimpannya karena jabatan pencahariannya, baik yang sekarang, maupun yang dahulu, diancam dengan pidana penjara paling lama 9 bulan atau denda paling banyak enam ratus rupiah.

2. Melindungi Notaris dari kemungkinan terkena sanksi administrative berdasarkan Pasal 85 UUJN yang menyatakan bahwa jika Notaris melanggar atau tidak melaksanakan kewajiban sebagaimana yang tertera pada Pasal 16 ayat (1) UUJN maka akan dikenakan sanksi berupa: teguran lisan, teguran tertulis, pemberhentian sementara, pemberhentian dengan hormat, atau pemberhentian dengan tidak hormat

b. Notaris dilindungi oleh hak Imunitas terhadap aktanya yang bermasalah. Hal ini untuk melindungi Notaris dalam konteks pembuatan akta yang secaraadministratif adalah benar, namun dalam proses pengkonstantir kedalam bentuk akta, terjadi manipulasi data oleh klient tanpa sepengetahuan Notaris.

Yang jika dirumuskan dalam bentuk rumusan peraturan perundangundangan sebagai saran bagi pembuat undang-undang, menurut penulis adalah :

1) Dalam hal mempertanggung jawabkan isi akta di dean hukum, Notaris tidak dapat dituntut baik secara pidana maupun perdata

2) Notaris tidak dapat dituntut, baik secara perdata ataupun pidana dalah rangka menjalankan profesinya dengan maksud dan iktikad baik, untuk kepentingan para pihak dalam hal pengkonstantiran isi akta. 


\section{Perlindungan Hukum Terhadap Notaris Yang Membuka Kerahasiaan Isi Akta di Pengadilan.}

Notaris merupakan suatu jabatan profesi yang menjadikan pembuatan alat bukti berupa akta autentik sebagai tugas utamanya.Akta autentik sendiri merupakan sebuah akta yang mengcover keinginan dari perseorangan atau para pihak, baik berupa badan hukum maupun tidak, yang menghadap dihadapan notaris. Notaris dalam proses pembuatan akta autentik tidak hanya mengkonstantir kehendak atau maksud dari para pihak tentang suatu perbuatan hukum tertentu, yang kemudian dituangkan dalam bentuk akta tertulis, namun juga ikut bertanggung jawab terhadap isi akta yang dibuatnya.

Terdapat tiga yanggung jawab notaris dalam hal menjalankan profesi jabatan sebagai pejabat umum yang berkaitan erat dengan akta, yaitu : (1) tanggung jawab seorang notaris secara perdata atas akta yang dibuatnya, hal ini berarti notaris memiliki tanggung jawab atas kebenaran materil dari suatu akta, dalam hal konstruksi perbuatan melawan hukum, baik aktif maupun pasif, sehingga yang menjadi unsur perbuatan melawan hukumnya hanya sebatas pada adanya perbuatan melawan hukum (adanya kesalahan dan pihak yang dirugikan); (2) tanggung jawab notaris secara pidana atas akta yang dibuatnya, hal ini dalam kapasitasnya seorang pejabat umum, bukan dalam kapasitas sebagai personal individu; (3) tanggung jawab notaris secara administrasi atas akta yang dibuatnya.

Dalam rangka menjaga kepercayaan yang telah diberikan oleh semua pihak terkait kewajiban sera kewenangan seorang notaris, dan juga kepentingan para pihak yang mempercayakan keinginan mereka dengan segala keterangan yang diberikanuntuk dikonstantirkan dalam bentuk akta yang berkekuatan hukum, maka notaris memiliki kewajiban untuk merahasiakan isi akta yang telah dibuatnya tersebut.

Ketentuan yang berkenaan dengan kewajiban bagi seorang notaris untuk merahasiakan isi akta yang dibuatnya, tertuang dalam Pasal 16 ayat 1 huruf f. Pasal tersebut menyatakan bahwa notaris harus: "merahasiakan segala sesuatu mengenai akta yang dibuatnya dan segala keterangan yang diperoleh guna pembuatan akta sesuai dengan sumpah/janji jabatan, kecuali undang-undang menentukan lain."

Terdapat peraturan perundang-undangan lain yang dapat dijadikan dasar hukum bagi notaris dalam hal "merahasiakan", yaitu Pasal 170 ayat 1 KUHAP, Pasal 1909 KUHPerdata dana Pasal 146 HIR ayat (3), dan Undang-Undang Nomor 5 Tahun 1986, diubah menjadi Undang-Undang Nomor 9 Tahun 2004, dan kembali diubah menjadi Undang-Undang Nomor 
51 tahun 2009 tentang Pengadilan Tata Usaha Negara, Pasal 89 ayat 1 huruf b.

Jika merujuk pada tiga peraturan perundang-undangan tersebut mengindikasikan bahwa terdapat suatu pembanaran dimana jabatan notaris diakui telah memiliki kewenangan untuk tidak bicara atau dengan spesifik, notaris dilarang untuk menyampaikan informasi tentang segala sesuatu mengenai keterangan kepada pihak tertentu yang menurut ketentuan undang-undang diperkenankan atau diperintahkan untuk mnegetahui isi akta tersebut.Oleh karena itu, sudah sekiranya setip notaris diberikan suatu bentuk perlindungan hukum.

Perlindungan hukum adalah sebuah bentuk usaha dalam rangka memberikan hak kepada seseorang yang memang sudah seharusnya dilindungi oleh hukum karena kewajiban yang diamanahkan kepadanya.Berkaitan dengan hal tersebur, perlindungan hukum dibedakan menjadi dua, yaitu perlindungan hukum preventif dan perlindungan hukum represif.

Perlindungan hukum preventif adalah bentuk perlindungan hukum yang bersifat sebagai pencegahan agar tidak terjadi suatu sengketa.Pada profesi Notaris yang tergolong dalam perlindungan hukum preventif sendiri adalah mengenai kecermatan seorang notaris dalam mengkonstantir apa-apa saja kehendak klien serta objek dari akta yang dibuatnya, notaris wajib memberikan informasi kepada kliennya mengenai hal yang boleh dan tidak boleh dalam peraturan perundang-undangan.Hal ini ditujukan agar notaris dan klien dapat terhindar dari masalah dikemudian harinya.Sedangkan perlindungan hukum represif adalah sebuah perlindungan hukum yang bersifat penyelesaian, yang berarti perlindungan hukum ini hadir pada saat sudah terjadinya sengketa.Dalam profesi Notaris yang bisa disebut sebagai perlindungan hukum represif adalah Hak Ingkar.

Notaris merupakan pejabat umum yang ditugaskan dan diberi wewenang berdasarkan undang-undang yang ada.Sehingga, yang mendapatkan perlindungan disini adalah jabatannya bukan perorangan notarisnya.Jabatan sendiri adalah pekerjaan (tugas) dalam pemerintahan atau keorganisasian. ${ }^{7}$

Sebagai subyek hukum, jabatan sendiri masuk dalam kategori persona (bukan badan hukum) yaitu sebagai pendukung dari adanya hak dan kewajiban yang melekat pada diri seseorang berkaitan dengan jabatan yang diembannya.Hal tersebut berkaitan erat dengan tugas dan wewenang yang yang terdapat dalam jabatan itu sendiri.Oleh karena itu, setiap profesi yang mengatasnamakan suatu jabatan haruslah sesuai dengan peraturan

${ }^{7}$ Departemen Pendidikan dan Kebudayaan, Kamus Besar Bahasa Indonesia, (Jakarta: Balai Pustaka, 1994), hal.29 
perundang-undangan yang ada, karena hal inilah yang kemudian menjadi payung hukum dalam pelaksanaan jabatannya.

Perlindungan hukum ialah dasar agar terlaksananya fungsi hukum dalam rangka mewujudkan hukum yang adil, bermanfaat, dan memiliki kepastian hukum.Perlindungan hukum merupakan perlindungan yang diberikan kepada subjek hukum sebagai jalan untuk melakukan pengawasan sehingga tidak terjadi sengketa.Dalam rangka menghindari terjadinya sengketa permasalahan hukum itu, maka pelaksanaan tugas dari jabatan notaris haruslah berpegangan pada standar profesinya, yang dalam hal ini adalah Kode Etik Notaris.

Agar terlaksananya pengawasan terhadap notaris dalam rangka pelaksanaan tugas dan wewenangnya sesuai kode etik maupun UUJN terkait upaya perlindungan hukum preventif, yang dapat dilakukan adalah memaksimalkan peranan Kementerian Hukum dan HAM sebagai badan kepemerintahan yang ruang lingkup kewenangannya berkaitan dengan bidang kenotariatan, dan dengan dibentuknya Majelis Pengawas yang keanggotannya tidak hanya dari notaris senior saja namun juga dari para pihak ahli dan akademisi. Hal ini dilakukan guna tercapainya para notaris baru yang professional dan berintegritas.

Tugas dari Majelis Pengawas Notaris secara umum adalah mengawasi jalan kerjanya para notaris, dan memeriksa jika terjadi pelanggaran terhadap kode etik ataupun pelaksaan tugs jabatan notaris, sebagaimana termuat dalam Pasal 70 huruf a, Pasal 73 ayat 1 huruf a dan b, Pasal 77 huruf a dan b UUJN. Dapat dituliskan secara singkat bahwa tugas Majelis Pengawas adalah memeriksa:

1. Adanya dugaan pelanggaran kode etik

2. Adanya dugaan pelanggaran pelaksana tugas jabatan, dan

3. Perilaku notaris yang diluar menjalankan tugas jabatnnya sebagai notaris.

Permasalahan yang sering terjadi selama ini adalah anggota Majelis Kehormatan Notaris memiliki pemahaman yang tidak sama tentang akta autentik. Tertuang dalam aturan Pasal 66A UUJN-P, Majels Kehormatan Notaris memiliki tugas untuk membina notaris. Dan menurut aturan tertulis Peraturan Menteri Hukum dan Hak Asasi Manusia Nomor 7 Tahun 2016 tentang Majelis Kehormatan Notaris Pasal 18 ayat 2, menyatakan bahwa tugas dari Majelis Kehormatan Notaris adalah menjaga martabat dan keharmonisan notaris dalam rangka menjalankan profesi jabatannya dan memberikan perlindungan hukum kepada Notaris yang kaitannya.

Untuk itu, MKN diharapkan dapat melaksanakan tugasnya dalam hal pembinaan kepada para notaris, dengan harapan dari pembinaan tersebut notaris akan lebih berhati-hati dalam melaksanakan tugas dan 
kewenangannya sebagai pejabat publiksehingga tidak tersandung masalah baik tindak pidana maupun perdata. MKN juga harus terus melakukan pendampingan dan pembekalan tentang kenotariatan, akta autentik serta keterkatian antara notaris, pihak yang menghadap, dan aktanya agar terjaga dan tidak bermasalah.

Menurut Ko Tjay Sing istilah yang digunakan adalah rahasia pekerjaan. Dalam rahasia pekerjaan dibedakan lagi menjadi dua rahasia, yaitu rahasia mutlak dan rahasia relatif. Beliau menjabarkan teori rahasia mutlak: dinamakan mutlak (absolute) dikarenakan wajib menyimpan rahasia pekerjaan dalam keadaan apapun, biasa atau luar biasa dan bagaimanapun wajib menyimpan rahasianya. ${ }^{8}$ Berdasarkan pengertian diatas maka notaris wajib merahasiakan isi dari akta dan keterangan yang diperolehnya karena jabatannya sampai kapanpun dan dalam kondisi apapun juga.

Sedangkan dalam teori rahasia relatif (nisbi), Ko Tjay Sing menyatakan hal yang bersebrangan dengan teori rahasia mutlak dimana: teori rahasia relative memandang bahwa seorang wajib penyimpan rahasia, bila dihadapkan sebagai saksi atau sebagai saksi ahli hendaknya ia memperhatikan apakah ia harus memilih hak tolak jika ada atau harus memberi kesaksian. ${ }^{9} \mathrm{Hal}$ ini bergantung pada hal dan situasi kongkret.

Kesaksian yang diberikan oleh wajib penyimpan rahasia dalam perkara perdata dapat merugikan atau menguntungkan salah satu pihak yang bereperkara, sedangkan dalam perkara pidana dapat memberatkan tertuduh. Apakah kekuatan pembuktiannya, jika dengan kesaksian tersebut, saksi dianggap telah melanggar kewajiban untuk menyimpan rahasia pekerjannya ? Dalam hal peraturan perundang-undangan untuk Notaris, belum ada muatan suatu peraturan tentang hal dimana Notaris pasti akan dilindungi jika diminta untuk menjadi saksi, seperti halnya Pers, Advokat, ataupun Bank. Bahwa berdasarkan ketentuan Pasal 322 KUHP ayat (1) menyatakan bahwa bagi siapapun yang dengan sengaja baik karna terpaksa maupun tidak diketahui membuka rahasia yang seharusnya menjadi kewajibannya dalam rangka melaksanakan kewajiban jabatannya, dapat dikenakan sanksi pidana 9 bulan penjara atau denda paling banyak Rp. 600,- Dan Pasal 322 KUHP ayat (2), berisikan lex specialis dari ayat (1), yang menyatakan jika kejahatan tersebut diperuntukan terhadap seorang atau kelompok, maka bagi orang yang melakukan tindakan melawan hukum tersebut hanya dapat dituntut atas pengaduan orang yang merasa dirugikan. Berdasarkan uraian pada dua pasal tersebut, jelas bahwa bagi mereka yang melakukan pelanggaran berupa membuka kerahasiaan akta yang oleh jabatannya dilarang dapat dijatuhi sanksi.

${ }^{8}$ Ko Tjay Sing, Op.Cit, hal.43.

${ }^{9}$ Ibid. hal. 47 
Notaris merupakan pejabat umum dengan kewajiban utama sebagai pejabat pembuat akta yang disumpah berdasarkan ketentuan Pasal 4 UUJN, yang mana frasa dalam sumpah tersebut adalah “...saya akan merahasiakan isi akta dan keterangan yang diperoleh dalam tugas pelaksanaan jabatan saya.. "dan didukung pula dengan ketentuan yang terdapat dalam Pasal 16 ayat 1 huruf e. Selain dua dasar peraturan tersebut, Pasal 170 KUHAP pun mengatur mengenai merahasiakan isi akta karan jabatan.

Upaya hukum yang dapat ditempuh jika notaris berada dalam posisi tidak menguntungkan dalam artian, seorang notaris dipaksa untuk membuka isi akta adalah dengan menggunakan Hak Ingkar sebagaimana disebut pada sub bab sebelumnya. Hak ingkar sendiri merupakan terjemahan dari kata verschoningsrech yang memiliki arti sebagai hak untuk dibebaskan dari memberikan keterangan sebagai saksi dalam suatu perkara, yang mengandung kewajiban dan hak untuk tidak bicara.Dari pengertian tersebut dapat dikatakan bahwa hak ingkar bukan saja merupakan hak bagi notaris namun lebih pada kewajiban seorang notaris untuk tetap merahasiakan isi akta dalam rangka melindungi kepentingan para pihak sebagai rahasia jabatannya kondisi apapun.

Hak ingkar yang notabenenya adalah hak yang melekat pada diri notaris, dalam hal proses pemeriksaan, baik itu tingkat penyelidikan, penyidikan, maupun pada proses persidanga, sikap seorang notaris adalah pasif. Maksudnya adalah, dalam rangka memberikan keterangan dalam persidangan, notaris hanya boleh memberikan keterangan sebatas yang berkaitan dengan teknis pelaksanaan jabatan saja.Bukan pada memberikan keterangan mengenai isi akta yang dikehendaki oleh para pihak.Keharusan menjaga rahasia ini tidak hanya untuk menjaga rahasia para pihak yang terkonstantir dalam akta tersebut, namun juga dalam rangka menjaga kehormatan dan martabat seorang notaris dalam rangka menjalankan profesi jabatannya.Maka dalam hal Hak Ingkar yang dilindungi adalah profesinya bukan pejabatnya.

\section{KESIMPULAN}

Konsep Imunitas hukum yang ideal bagi notaris dalam pandangan penulis adalah: a) Notaris dilindungi oleh hak Imunitas saat membuka rahasia isi akta. Hal ini untuk melindungi Notaris dalam konteks membuka rahasia akta yang seharusnya tidak boleh dibuka di depan umum (pengadilan). Imunitas ini diharapkan dapat memberi perlindungan hukum bagi notaris dari kemungkinan terkena ancaman pidana berdasarkan Pasal 322 ayat (1) KUHP dan ancaman sanksi administrasi berdasarkan ketentuan Pasal 85 UUJN, b) Notaris dilindungi oleh hak Imunitas terhadap aktanya yang bermasalah. Hal ini untuk melindungi Notaris dalam konteks 
pembuatan akta yang secara administratif adalah benar namun dalam proses pengkonstantir kedalam bentuk akta, terjadi manipulatif data oleh klient tanpa sepengetahuan Notaris.

Terdapat suatu pengakuan bahwa notaris memiliki kewenangan untuk tidak bicara atau secara spesifik dilarang untuk memberikan informasi mengenai keterangan dari kilen yang dituangkan dalam bentuk akta. Perlindungan hukum prefentif bagi notaris adalah berupa pembinaan bagi notaris, kecermatan dalam mengkonstantir kehendak klient menjadi akta, serta keharusan notaris memberikan informasi kepada klien mengenai objek yang boleh dan tidak diperbolehkan oleh Undang-Undang. Sedangkan, perlindungan hukum represif berupa Hak Ingkar.

\section{DAFTAR PUSTAKA}

Departemen Pendidikan dan Kebudayaan. 1994. Kamus Besar Bahasa Indonesia, Jakarta: Balai Pustaka.

Ko Tjay Sing. 1978. Rahasia Pekerjaan Dokter dan Advokat. Jakarta: PT Gramedia.

Sudikno Mertokusumo, "Arti Penemuan Hukum Bagi Notaris", Majalah Renvoi, Nomor 12

https://osf.io/ag3vh/Laurensius Arliman S., "Ingkar (Verschoningsplicht) Atau Kewajiban Ingkar (Verschoning Splicht) Notaris Didalam Undang-Undang Jabatan Notaris”, Jurnal hukum Doctrinal, Vol. 1, Nomor 1, 2016 